Jurnal Ekonomi Pembangunan, 18 (2), 2017, 225-238

\title{
Loan-to-Value Ratio and Housing Price Cycle: Empirical Evidence from Indonesia
}

\author{
Charvin Lim*, Siwi Nugraheni \\ Department of Economics and Development Studies \\ Faculty of Economics, Parahyangan Catholic University \\ *Corresponding Author: charvin.kusuma@unpar.ac.id
}

Received: August 2017 | Revised: November 2017 | Accepted: November 2017

\begin{abstract}
The subprime mortgage crisis in 2007-2009 which led to a global recession has highlighted the importance of regulating credit for housing market. The urgency arises not only to manage non-performing ratio, but further to manage price in the housing market which is a potent source of financial imbalance. Loan-to-value (LTV) regulation is imposed in order to dampen the housing price cycle, preventing the occurrence of bubble issue. This study tries to capture the influence of LTV implementation on housing price and assesses its effectiveness in the national scope. Error correction model is used to portray the short and long-term dynamics of housing cycle with regard to policy, macroeconomic, and financial variables. We concluded that LTV is an effective policy to dampen the price cycle in the long run, but not in the short run. In the short run, housing price is closely determined by the macroeconomic factors. Furthermore, we found that the implementation of LTV has made housing price to become more persistent, suggesting a change in the market expectation structure and the behavior of housing price cycle.
\end{abstract}

Keywords: Macroprudential policy, financial stability, housing price.

JEL Classification: E58, G21, G28, R31

How to cite: Lim, C., \& Nugraheni, S. (2017). Loan-to-Value Ratio and Housing Price Cycle: Empirical Evidence From Indonesia. Jurnal Ekonomi Pembangunan: Kajian Masalah Ekonomi dan Pembangunan, 18(2), 84-97. doi:https://doi.org/10.23917/jep.v18i2.4846

DOI: https://doi.org/10.23917/jep.v18i2.4846

\section{Introduction}

The global financial crisis reminds us not only the urgency of financial stability, but also, the importance of housing cycle in determining macroeconomic soundness. The catastrophe eliminates the prior belief of price stability being adequate to maintain sustainable growth. Instead, households' and financial institutions' assets price bubble could also trigger a crisis. Housing is a valuable component of asset, both for households and financial intermediaries. With the nature of having immense value, it governs the largest proportion of wealth for most households - and a significant portion of assets for financial institutions. Shwartz (2012) mentioned that the size, the scope, and the price nature of housing are the underlying reasons why issues on mortgage debt could systemically damage the financial system and the economy. He highlighted that out of 19 OECD countries he observed, 9 of them have mortgage debt size that were larger than the equity market in the pre-crisis period. Interpreting its significance, a crisis on housing market would have a considerable scale and dispersal effect on the households and financial sector. Furthermore, having volatile price while 
recognized as collateral assets, housing also establishes strong influences on households' (hence aggregate) consumption and investment decision $^{1}$ (Iacoviello, 2005).

In addition, housing price cycle also determines the performances of financial intermediaries. As most housing purchases utilize external funding service, the purchases transform into assets (as mortgage) for financial intermediaries. Therefore, the dynamics of mortgage servicing affects the profitability and soundness of financial institutions. The swings in housing price, on the other hand, affect the mortgagor by altering the marginal benefit and marginal cost in paying the loan installments. Realizing these, it is of paramount for central banks to monitor and regulate housing cycle in order to create a sound financial system and stable macroeconomic condition.

To begin with, it is necessary to understand the relationship between housing price cycle and house financing services. Since majority of housing purchases are undergone through mortgage, the financing conditions and requirements play an essential role in forming the demand which in turn would affect housing price cycle (Tsatsaronis $\& \mathrm{Zhu}, 2004)$. The availability, cost, and flexibility of house financing are considered as the financing aspect which significantly influences housing demand. Grasping this fact, financial authority imposes limit on loan-to-value (LTV) ratio as a measure to control housing credit. LTV ratio governs the maximum proportion of housing value which can be disbursed as loan (availability). Thus, it sets the amount of minimum down payment (flexibility) and loan servicing (cost). The implementation of this policy is expected to suppress default rate, while also influence housing demand and prices. The effectiveness, however, has yet been tested, particularly for the dynamics of housing cycle in Indonesia.

LTV policy has been officially implemented in Indonesia since March 2012, with various adjustments until the current period. In the price.

${ }^{1}$ The wealth effect generated by movement in housing

Jurnal Ekonomi Pembangunan, ISSN 1411-6081, E-ISSN 2460-9331 first year, LTV is particularly implemented only on housing which are bigger than 70-squaremetre, with the notion of limiting overoptimistic expectation by investors in large houses. Later in September 2013, the regulation is revised to cover all sizes of houses, including small housing (less than 21-square-metre) and medium housing (22-square-metre to 70-square-metre), in order to regulate housing market comprehensively. Since the implementation, LTV ratio in Indonesia has been adjusted four times, starting from $70 \%$ in March 2012, to $80 \%, 85 \%$, and back to $80 \%$ consecutively in September 2013, June 2015, and August 2016. The adjustments are made in order to ensure housing market stability based on the perceived condition by the central bank of Indonesia.

Indonesiaisanemerging marketeconomy with two unique characteristics, a rapid development of financial sector and a vast productive generation. While financial innovations and derivatives are expected to promote growth, it exposes financial institutions to a higher systemic risk. It also influences financing conditions which would drive housing demand and its price dynamics (Glindro, Shubanij, Szeto, \& Zhu, 2011). In Indonesia, credit to GDP ratio stands at an average rate of $32.07 \%$ in $2012-2015$. In these periods, credit grows at an average rate of $15.82 \%$ per year with mortgage debts account for approximately $22.77 \%$ of the overall credit ${ }^{2}$. These numbers dictate the importance of housing market for financial sector and Indonesian economy.

The latter factor portrays demographic contribution to high demand in housing asset. Indonesia stands as the fourth most populated country in the world with current population of approximately 265.03 million, growing at about $1.25 \%$ per annum, with $49.63 \%$ of the population being in the labor force ${ }^{3}$ depicting a high level of productive generation. On the other hand, it is the mandate of the Indonesia's 1945 basic constitution

${ }^{2}$ Data is obtained from Indonesian Banking Statistic and is processed by the Author.

${ }^{3}$ Data is obtained from Indonesian Statistic Bureau and is processed by the Author. 
(UUD 1945) article 28(H) that the state has responsibility to provide adequate housing for all citizens. The government of Indonesia (at central, provincial, and district levels) has implemented policies to reduce housing backlog even since the Kampung Improvement Programme of 1978. However, data from the Ministry of Public Works and Housing show that in 2015, there are still 7.6 million of housing backlog. One of the challenges to reduce housing backlog is the LTV regulation, because the vast majority of housing provision is through financial institution. Noting the high level of productive generation and the sluggish development of housing supply, this factor potentially brings about excess demand, nurturing asset price bubble issue (Igan \& Loungani, 2012), and even possibly impairs the effectiveness of LTV regulation. Reflecting on these potent sources of financial imbalances, it is urgent for authority to understand the dynamics of housing cycle and to have reliable instruments which are capable of altering and stabilizing housing price.

Thus, our study tries to identify and assess the factors determining housing price in Indonesia, taking into account the dynamic effect on different time horizon. In addition, we also assess the effectiveness of LTV instrument (macroprudential) and interest rate (monetary) in dampening the housing price cycle. Providing insights regarding these matters, the study is expected to point out instruments and policy alternatives to manage the amplitude of housing cycle, preventing asset price bubble issue and creating a sound housing market which supports stable financial system and macroeconomic condition.

Previous stream of literatures had identified asset price bubble as the source of financial system fragility. Allen and Gale (2000) pointed out the three phases of asset pricing bubble, starting from the credit expansion (due to financial liberalization or encouragement to increase credit disbursement) which inflates the asset price, continuing to the phase when the bubble burst, and ends with defaults by agents due to fall in their assets value. The third phase is commonly followed by banking crisis and or foreign exchange pressure, as the central bank is faced to the dilemma between saving the banks or maintaining currency stability. Noting the notorious impact of asset price bubble, many influential economists tried to model the source and possibility of price bubbling to occur. While notable studies argued the improbability of price bubble to occur in an economy with rational agents (see Tirole (1982) and De Long et al. (1990)), others incorporate market imperfection and infinite time horizon and found the results supporting the possibility of price bubble to occur in rational environment (see Tirole (1985) and Allen \& Gorton (1993)).

Further identification on the sources of bubble led to remodeling of asset price, including to model the fundamental price of housing. The fundamental value of housing is defined as the expected present value of future income or services which the house might generate in the future. It includes the discounted present value of rent and resale value. Two theoretical innovations are proposed by Allen and Gale (2000), integrating risk shifting and credit expansion as the sources of housing price deviation from its fundamental value. They urge the importance of credit expansion as it has direct and indirect effect to housing price through expectation. Further development of housing pricing model by Glindro et al. (2011) construct three bloc of movement sources in housing price. The first bloc representing the source of fundamental movement, which are the economic and institutional development. The second bloc attributed the cyclical term of housing price movement explained by the autocorrelation of housing price, while the third consists of irrational expectation component represented by error term. While in the long run housing price is expected to return to its fundamental value, in the short term, however, deviation might occur because of cyclical or bubble-related issue.

In the aftermath of the great recession 2007-09, there has been growing concerns 
Jurnal Ekonomi Pembangunan, 18 (2), 2017, 225-238

regarding macroprudential regulation for maintaining macro-financial stability. One aspect of macroprudential perspective which had been adopted by most economies is the importance of regulating housing market. Rather than the product of economic cycle, there has been growing consensus of housing market being an important drive to the economic growth. Its contribution is proven by the high correlation between aggregate consumption and housing wealth (Iacoviello, 2010). Catte et al. (2004) argues that there has been a "housing wealth effect", where increase in housing value creates incremental-wealth for house owners, encouraging them to consume and invest more, vice versa. Iacoviello (2010) also argues that housing asset is widely acknowledged as a reliable collateral, therefore an increase/ decrease in housing value would determine the capability of homeowners to borrow. This condition further affects household consumption and investment behavior.

In the same sense, housing market also affects the soundness of financial institutions. Housing purchases are typically financed with a down payment, and a mortgage to make up for the remaining value (the difference between the house price and down payment). Thus, a default on mortgage would hamper the condition of the lender (the financial institution). Housing price also influence the performance of financial institution in three ways. Firstly, movement in housing price would affect the marginal benefit of borrowers in servicing their mortgage loan (altering default risk). Secondly, housing price will affect the collateral value held by banks (mortgage disposal value provided default) therefore defining their balance sheet condition. Thirdly, as collateral, housing wealth determines how much a bank can lend to the potential borrower. The seminal contribution of Kiyotaki and Moore (1997) points out the source of financial frictions being the collateral constraint. In their economy, lenders cannot force borrowers to pay their debt, resulting the need of collateral to back-up each loan. As housing is the widely-accepted collateral, its value would govern households borrowing capability, influencing their consumption, saving, and investment decisions which drives the macroeconomic performance.

To manage housing cycle, macroprudential approach proposes LTV regulation. The idea is to limit the friction generated in housing market by cutting the permitted amount of loans to a proportion of housing value. Through optiontheoretic approach of mortgage default ${ }^{4}$, we know that higher down payment leads to lower default risk. This is due to the higher stake the borrowers have on the house, giving him higher incentive to continue servicing the loan. Deng et al. (2000) add that borrowers who are unable to provide higher down payment are more likely to suffer from liquidity constraint, thus has higher default risk. On the other hand, LTV is also employed to dampen the growth of mortgage credit and housing price. Adjusting LTV ratio would alter the required down payment in purchasing a house with mortgage, thus would also alter the demand for mortgage and housing. Evaluating the effectiveness of LTV, Morgan (2015) studies the emerging economies in Asia and found that countries who implement LTV regulation experience lesser expansion in mortgage loans compared to those countries who did not. The result indicates the usefulness of this instrument to dampen mortgage boom. Applying MM-estimator (which add weight on observations to accommodate outliers), they also found that LTV plays a more dominant role in influencing mortgage loans compared to house prices, GDP, exchange rate and stock price index.

Wongetal.(2011)also studiestheeffectiveness of LTV and its drawback in addressing systemic risk. Observing thirteen economies of developing and developed countries, they found that LTV is an effective instrument to dampen the property markets' boom-bust cycle. The instrument is also found to reduce the sensitivity of default risk toward shocks on property prices, safeguarding financial intermediaries over mortgage default risk. However, the analysis suggests that LTV

${ }^{4}$ See Elu (2006) for a detailed explanation of option-theoretic approach of mortgage default. 
also puts up liquidity constraints for mortgage borrowers, suggesting an expected consumption slowdown if not addressed properly. They infer that the reduction in systemic risk is caused by the declining household leverage over tight LTV caps.

Another study comprehensively assesses the influence of LTV and debt-to-income (DTI) caps on housing price in Korea (Igan \& Kang, 2011). Empirical evidence is provided regarding the impact of these instruments on housing price, market activity, and the leverage of household. Igan and Kang (2011) found that the tight stance of LTV and DTI is associated with slower housing price appreciation and, also, a decline in mortgage transactions. The effect started with a drop on housing market transactions (3-month after policy implementation) and followed by declining housing price (6-month). They also found that LTV is more effective in repressing housing price volatility compared to DTI. Moreover, it is argued that changes in the instruments' caps would alter market expectation regarding future housing prices, which influence the purchasing decisions of housing and create a self-fulfilling prophecy of declining/increasing price. This study, however, only found a weak association between mortgage loan condition and household leverage, challenging the notion of housing wealth effect.

Another stream of literature employs Dynamic Stochastic General Equilibrium (DSGE) model in assessing the influence of LTV, as a macroprudential instrument, on housing price and macroeconomic as a whole. Initiated by the seminal contribution of Iacoviello (2005), many studies utilize the notion of collateral constraint as the source of financial friction to explain the impact of imposing LTV on housing price dynamics (see Rubio \& Carrasco-Gallego (2014) and Iacoviello \& Neri (2010)). The development of this analysis tool also allows researcher to infer the effect of endogenous LTV (See Funke and Paetz (2012)) and its combination with monetary instrument (see Angelini et al. (2012)). While the studies generally found LTV policy being an effective instrument in dampening housing price dynamics, the result is very sensitive to the specification and parameterization of the DSGE model.

\section{Methods}

Our study uses secondary data retrieved from Indonesian Central Bureau of Statistics, Financial Services Authority (OJK), and Bank Indonesia. We use quarterly time series data from 2003Q1 to 2017Q1, which is the most recent available data. To explain the general behavior of housing price movement in Indonesia, we utilize an aggregated housing price as our dependent variable. Table 1 explains the data in a more detailed fashion.

We adapt the model of Tsatsanoris and Zhu (2004) and Andrews (2010) in determining the factors influencing housing price ${ }^{5}$. The independent variables can be divided into three groups, which are the macroeconomic condition, financial development, and policy variable. The macro condition is represented by household disposable income and inflation, while mortgage credit and stock market index depicts the financial development. Finally, short-term real rate represents monetary stance, while macroprudential policy is represented by LTV ratio. Firstly, a graph analysis of quarterly housing data from 2003-16 will be presented to provide a general insight of recent housing cycle development. The analysis continues to statistical approach using Error Correction Model (ECM) to capture the dynamics of housing cycle facing adjustments in LTV ratio.

The selection of independent variables in our model are based on adaptation of Tsatsanoris and Zhu (2004) and Andrews (2010) who have comprehensively apprehended the factor determining housing price on a large number of countries. Some adjustments are made to accommodate the feature of our data, the housing market in Indonesia. The general notion is to

${ }^{5}$ Both studies evaluated the cross-country evidences of housing price movement, each in Developed and OECD countries. 
Jurnal Ekonomi Pembangunan, 18 (2), 2017, 225-238

Table 1 Research Variables

\begin{tabular}{|c|c|c|}
\hline Denotation & Variables & Note \\
\hline$H I$ & Housing price & $\begin{array}{l}\text { Residential property index (IHPR) which mea- } \\
\text { sures aggregated house prices (for small, medi- } \\
\text { um, and large houses) in } 16 \text { major cities of Indo- } \\
\text { nesia. Log-linearization is performed on IHPR for } \\
\text { a meaningful interpretation. }\end{array}$ \\
\hline$G D P C$ & GDP per capita & $\begin{array}{l}\text { GDP per capita measures the size of economic ac- } \\
\text { tivities divided by population, which portrays the } \\
\text { development of households' disposable income. }\end{array}$ \\
\hline$\pi$ & Inflation rate & $\begin{array}{l}\text { Reflects overall price changes faced by house- } \\
\text { holds in the set of consumption goods. }\end{array}$ \\
\hline$i$ & Short-term interest rate & $\begin{array}{l}\text { Short-term rate for consumption loan, which de- } \\
\text { pict monetary stance. }\end{array}$ \\
\hline$I H S G$ & Stock market index & $\begin{array}{l}\text { IDX Composite (IHSG) depicts the average stock } \\
\text { price traded in Bursa Efek Indonesia. We use the } \\
\text { log-linearized form of IHSG. }\end{array}$ \\
\hline$C R$ & Mortgage loan & $\begin{array}{l}\text { Outstanding mortgage loan by conventional } \\
\text { banks in Indonesia. }\end{array}$ \\
\hline$L T V$ & Loan-to-value ratio & $\begin{array}{l}\text { A regulation set by the government to limit the } \\
\text { legal amount of mortgage loan generated based } \\
\text { on the housing value. }\end{array}$ \\
\hline
\end{tabular}

grasp how macroeconomic condition, financial development, and policy variable may affect housing price. Tsatsanoris and Zhu (2004) focused on how the condition of mortgage market and interest rate affect housing price. On the other hand, Andrews (2010) centered his study on the influence of macro and regulation aspects to housing price. As further development, in order to understand better the dynamics of relation between the covariates and housing price, we accommodate short and long-term analysis in our study.

Following Engle-Granger approach, we construct an ECM for housing price. The approach is chosen as our data behavior fits the modelling approach appropriately, yielding a strongly robust result. ECM also provides advantage in form of extensive longrun and short-run time series analysis, while also produces error correction term which deliver insight regarding the time needed for housing market to reach its equilibrium state. This information is crucial since price bubble emanates gradually, preventing the price to go back to its fair-steady condition. Best guess of equilibrium state and time required to achieve it might be proven useful to identify the malign diverging movement.

We firstly consider the stationarity behavior of each series. As our finding suggests non-stationarity series with order of integration I(1) for some variables, we continue to test for the possibility of cointegration. Our long run equation is constructed as follows:

$$
\begin{aligned}
& \log \left(H I_{t}\right)=\alpha_{1}+\beta_{1} G D P C_{t}+\beta_{2} C R_{t}+\beta_{3} \log \left(I H S G_{t}\right)+\beta_{4} L T V_{t}+\varepsilon_{t} \\
& \Delta \log \left(H I_{t}\right)=\gamma_{1} \Delta i+\gamma_{2} \pi+\gamma_{2} \Delta G D P C_{t}+\gamma_{3} \Delta C R_{t}+\gamma_{3} \Delta \log \left(I H S G_{t}\right)+\gamma_{4} \Delta L T V_{t} \\
& +\gamma_{5} \varepsilon_{t-1}+\gamma_{6} d+\gamma_{7}\left(d \times \Delta \log \left(H I_{t-1}\right)\right)+u_{t}
\end{aligned}
$$


IHPR and IHSG are index for residential property and stock market respectively. To provide a meaningful interpretation for indexes, we transform them to the log-linearized form. From the estimation result of the long-run model, we observe the error terms in order to prove the existence of cointegration. A formal stationarity test is performed for the residual. If the linear combination of these $\mathrm{I}(1)$ series yield a stationary result, it means that cointegration exist, otherwise not. We continue by forming the short-run equation, structured as above (2)

Equation 2 depicts the parsimonious form of the short-run equation, by which meaningless insignificant variables are already eliminated. is a dummy variable with value 0 depicting periods without LTV regulation, and 1 otherwise. The purpose of adding dummy variable is to identify the changes of behavior in residential property price before and after LTV implementation. The interaction variable depicts autoregressive behavior of housing price after LTV regulation is enforced. Lastly, the coefficient of long-run lagged residuals, is the error correction coefficient expressing the extent of price correction the rate of convergence to equilibrium state in each period (quarterly).
Through this method, we expect to produce comprehensive analysis of relationship between observed variables in the short and long-time horizon. The output is expected to provide insight particularly regarding the housing cycle in Indonesia and its dynamics toward adjustments in LTV ratio and interest rate, which are the important macroprudential and monetary instruments of Indonesian central bank in achieving financial and price stability.

\section{Results And Discussion}

Residential housing price in Indonesia shows an upward sloping development with turbulent movement in some periods, most notably in the late 2012 to 2013 - when LTV is implemented for the first time. The sample period shows that housing price rises from one period to another without having a single negative change. The rate of increase, however, is volatile. Figure 1 below suggests a non-stationary housing price with positive deterministic trend. Note that positive deterministic trend does not necessarily means a process of price bubbling, rather it may show a natural benign increase in housing value.

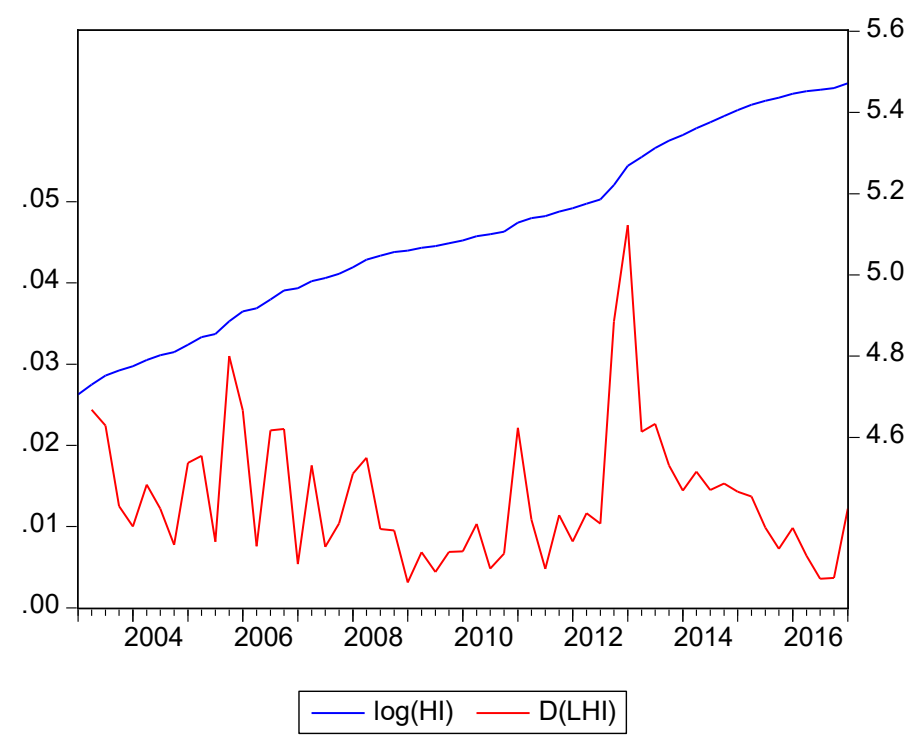

Figure 1 IHPR development 2003Q1 - 2017Q1 
Jurnal Ekonomi Pembangunan, 18 (2), 2017, 225-238

In order to formally test the order of integration of all variables observed, we perform Augmented Dickey-Fuller (ADF) tests. Equation

$\Delta y_{t}=k_{1}+k_{2} T+k_{3} y_{t-1}+\sum_{i=1}^{p-1} \vartheta_{i} \Delta y_{t-i}+\epsilon_{t}$

$\Delta^{2} y_{t}=k_{1}+k_{3} \Delta y_{t-1}+\sum_{i=1}^{p-1} \vartheta_{i} \Delta^{2} y_{t-i}+\epsilon_{t}$

where is the variable tested, is a deterministic trend, and is the residual series. Table 2 summarizes the ADF test results. As expected, some series have non-stationary characteristic and can be specified as I(1), including the IHPR, mortgage loan, GDP per capita, IHSG, interest rate, and LTV.

The finding of I(1) series amongst dependent and independent variables yield two conclusions. First, we are not allowed to run ordinary least squares (OLS) estimation technique directly using the raw data, as linear combination of nonstationary series might produce non-stationary residuals, hence spurious regression result. On the other hand, the non-stationary series allow
3 and 4 express the $\mathrm{ADF}$ test equations for level and first-differenced series respectively.

us to test for cointegration. If cointegration relationship exists amongst the series, a linear regression on these variables will produce a stationary error series and super-consistent estimators (Engle \& Granger, 1987). Based on these assumptions, we run equation (1) through OLS technique. We exclude short-term interest rate from the long-run equation for two reasons. First, assuming households do not have perfect information to form expectation regarding future short-term rate, the current short-term rate would not affect housing price in the long run. It would, however, affect contemporaneous decisionmaking of households in applying for mortgage.

Table 2 Summary of ADF Test Results

\begin{tabular}{cccc}
\hline Series & Optimal lag length (SC) & ADF Statistic $^{\mathbf{1}}$ & Inference $^{\text {Ond }}$ \\
\hline $\log (H I)$ & 1 & -0.4962 & $\mathrm{I}(1)$ \\
$\Delta \log (H I)$ & 0 & -0.5634 & $\mathrm{I}(0)$ \\
$C R$ & 0 & 0.0155 & $\mathrm{I}(1)$ \\
$\Delta C R$ & 0 & -0.9764 & $\mathrm{I}(0)$ \\
$G D P C$ & 5 & -0.7241 & $\mathrm{I}(1)$ \\
$\Delta G D P C$ & 4 & -2.6797 & $\mathrm{I}(0)$ \\
$\log (I H S G)$ & 1 & -1.9803 & $\mathrm{I}(1)$ \\
$\Delta \log (I H S G)$ & 0 & -5.2098 & $\mathrm{I}(0)$ \\
$L T V$ & 0 & -1.2939 & $\mathrm{I}(1)$ \\
$\Delta L T V$ & 0 & -7.3093 & $\mathrm{I}(0)$ \\
$i$ & 3 & -1.6309 & $\mathrm{I}(1)$ \\
$\Delta i$ & 0 & -2.9459 & $\mathrm{I}(0)$ \\
$\pi$ & 3 & -4.5526 & $\mathrm{I}(0)$ \\
\hline
\end{tabular}


Second, there is no plausible explanation of how short-term interest rate may affect housing price behavior on the long run. Borrowers always have the option to do a refinancing if the future rate is lower than the present. Expectation regarding future short-term rate, on the other hand, would affect housing price, but our model does not accommodate the possibility ${ }^{6}$.

Table 3 Long-run Regression for Housing Price

\begin{tabular}{ccccc}
\hline Variable & Coef. & Std. Error & t-Statistic & p-value \\
\hline$\alpha_{1}$ & 4.0676 & 0.0919 & 44.2788 & $0.0000 *$ \\
$C R$ & 0.0013 & 0.0002 & 7.6013 & $0.0000 *$ \\
$G D P C$ & 0.0065 & 0.0061 & 1.0603 & 0.2939 \\
$I H S G$ & 0.0843 & 0.0137 & 6.1520 & $0.0000 *$ \\
$L T V$ & 0.0012 & 0.0004 & 2.6894 & $0.0096 *$ \\
\hline \multicolumn{5}{c}{ *indicates significance at the 99\% level }
\end{tabular}

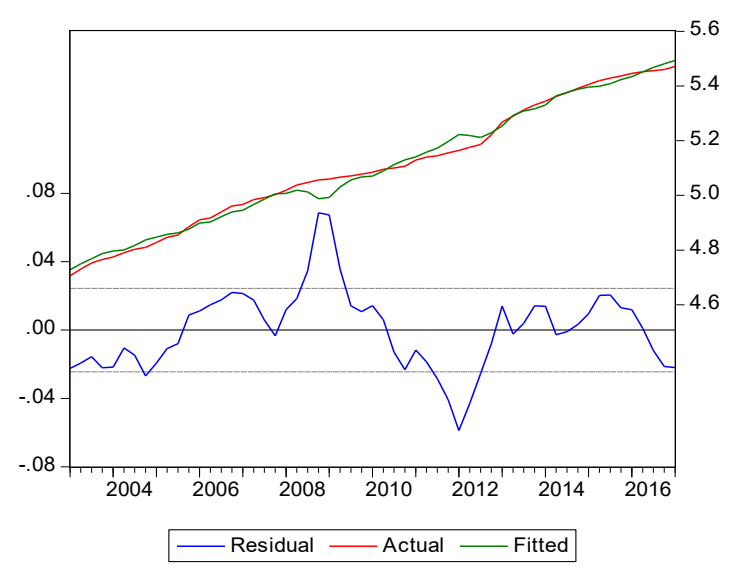

Figure 2 Long-run Regression Line and the Residual Series

Table 3 demonstrates the long-run estimation result. The R-squared of 0.9892 indicates that the dependent variable (residential property price index) is strongly explained by the independent variables. However, since the observed variables are integrated in order one (I(1)), we need to check for cointegration to ensure that the estimation is consistent. Figure 2 graphs the regression lines

${ }^{6}$ Method of moments might be useful to study the effect of expectation regarding future interest rate on housing price. Our study, however, does not hold on this focus. along with the residual series. It suggests a stationary residual series, however with strong deviations in some years, e.g. 2009 and late 2011. Following Engle-Granger approach, we formally test the residuals' stationarity through ADF test.

The residual series is found to be stationary with ADF statistic of -2.9699 (stationary in $95 \%$ confidence level). Correlogram of the series indicates a constant covariances and the non-existent of autocorrelation, suggesting a robust estimation of the model. Thus, having super-consistent estimators, we found that the explanatory variables - per capita GDP, mortgage loan, stock market index, and LTV significantly affect housing price cycle in the long run. The result suggests that the time-trend of residential housing price is fully explained by the explanatory series.

Mortgage loan is found to have positive effect on housing price. More specifically, an increase of a trillion rupiah in mortgage loan raises residential housing price by $0.13 \%$. The result is in accordance with Taltavull de La Paz and White (2012) who suggest that mortgage credit plays a critical role in forming the effective demand for housing. In this study, we also found that the mortgage loan affect housing price through demand. It allows household to purchase housing without having a huge amount of money equal to the housing value, rather it requires the households' future expected income as the payment. Through easing the condition for purchasing a property, it allows more households to buy residential housing, raising its demand, hence price.

Supporting the finding of Andrews (2010) we also found that housing price rises proportionally with households' income. A raise in household income is also found to positively affect the price of housing. The estimation result suggests that a million increase in per capita GDP will boost housing price by $0.65 \%$. Similar to other normal goods, as the income of household increases, so does the demand for housing. The increase in housing demand coupled with sluggish supply growth, then raises the price of housing. 
Jurnal Ekonomi Pembangunan, 18 (2), 2017, 225-238

Further, we found that stock market also shows a strongly positive relation to housing price. A percentage increase on stock market index is followed by $0.08 \%$ increase in the housing price. The result is in contrary with Eddie and HuiShen Yue (2006) who found that stock index does not have influence on housing price in Beijing and Shanghai, while also urging substitutive relationship between the two in Hong Kong. They argue that housing and stock are substitutes as investment alternatives in urban households (Hong Kong), therefore a strong performance in the stock index would translates into strong movement in housing demand and price. Our finding conforms Poterba (2000) instead, suggesting the existence of wealth effect from capital gain in holding securities, which affect the demand for other investment instruments including housing. Our result reflects that housing and stock do not substitute each other as investment alternatives in Indonesia, rather they have complementary relationship.

Moving to the policy instruments, the macroprudential policy variable (LTV) is found to have a positive long-run effect on housing. $1 \%$ increase in loanable housing value would translate into a boost of $0.12 \%$ in housing price. It indicates that a looser LTV stance (higher LTV) can effectively raise housing price, while stricter LTV (lower LTV) is capable of hampering housing price growth. The result affirms the effectiveness of LTV instrument as have been found by previous literatires (Igan \& Kang (2011) and Tsatsaronis and Zhu (2004)). To be more specific, our finding confirms the effectiveness of LTV as an instrument to control housing price in Indonesia.

Table 4 shows the ECM estimation result, depicting the short run relationships amongst the observed variables. The dependent variable of the error correction model is the first-differenced form of log linearized housing price. The ECM states that changes in the explanatory variables would proportionally translates into changes in the dependent variable. From the estimation result, we found that some variables which affect housing price in the long run turn out to have no contemporaneous effect. This includes the mortgage loan, per capita income, and the LTV ratio. It indicates that it takes time for these variables, including LTV policy, to be able to properly bring about influence on the dynamics of housing cycle.

The stock market index, on the other hand, dynamically influence housing price both in the short and long run. The short run effect, however, is found to be much weaker. The finding is in line with Carroll, Otsuka, and Slacalek (2011) who studied the dynamics of wealth effect on consumption and found that the immediate wealth effect is substantially weaker than its eventual

Table 4 Error-Correction-Model for Change in Housing Price

\begin{tabular}{ccccc}
\hline Variable & Coef. & Std. Error & t-Statistic & p-value \\
\hline$\Delta i$ & -0.0028 & 0.0024 & -1.1740 & 0.2463 \\
$\pi$ & 0.0015 & 0.0001 & 11.3095 & $0.0000^{*}$ \\
$\Delta C R$ & 0.0000 & 0.0000 & -0.1928 & 0.8479 \\
$\Delta G D P C$ & 0.0000 & 0.0028 & 0.0046 & 0.9964 \\
$\Delta \log (I H S G)$ & 0.0200 & 0.0057 & 3.5104 & $0.0010^{*}$ \\
$\Delta L T V$ & 0.0001 & 0.0002 & 0.6762 & 0.5022 \\
$\varepsilon_{t-1}$ & -0.0897 & 0.0315 & -2.8491 & $0.0065^{*}$ \\
$d$ & -0.0061 & 0.0021 & -2.9536 & $0.0049 *$ \\
$d \times \Delta \log \left(H I_{t-1}\right)$ & 0.8569 & 0.1041 & 8.2331 & $0.0000^{*}$ \\
\hline
\end{tabular}

* indicates significance at the $99 \%$ 
effect. In our case, a percentage change in stock market index only change the housing price by $0.02 \%$ (four times weaker compared to the long run effect). This suggests a gradual influence of the stock market index to housing dynamics.

On the other hand, interest rate and inflation is found to only have short run effect on housing price cycle. Inflation naturally have positive influence on housing price, since housing is one of the basic needs. An increase of price in general also causes housing price to rise. In this case the influence is found to be small, where a percentage change in inflation would generate a $0.15 \%$ change in housing price. Moving to the second policy variable, we found that interest rate has an inconsistent short-term relation to housing price. While the effect of short-term interest rate is found to be statistically insignificant, the direction of the coefficient (negative) confirms the negative relationship between tight monetary stance and housing price growth. The effect, however, is not consistent enough to be statistically significant in 99\% confidence level. Our finding regarding the effect of interest rate is in accordance to Wilson et al. (2011) who found that interest rate could only weakly affect housing price in the short-run, but has no effect in the long run.

The error correction term is found to have a negative coefficient, conforming the congruity of the data with the modelling approach. It also proves the cointegration relationship amongst the observed variables in equation (2). The negative coefficient indicates that the deviations created in the short run dynamics would be corrected overtime and the equilibrium state would be achieved. The result suggests that in each period - or each quarter - the extent of correction term is $8.97 \%$. This shows a slow speed of convergence to the equilibrium condition relating to housing market. Equilibrium condition would approximately be achieved in 11.14 quarters (nearly 3 years) after a shock. The slow rate of convergence may be related to the rigid housing market, with its illiquid characteristic, high transaction cost, and a relatively far-from-perfect

\section{information.}

We also found a change in the behavior of housing price and expectation between the period before and after LTV policy implementation. In this case, housing price growth in the period after LTV implementation tend to have lower mean ( $0.61 \%$ lower) compared to the previous periods. While the result is statistically significant, this condition needs to be investigated further as our sample only includes 20 periods (5 years) in which LTV regulation is active. Furthermore, we found a change in the expectation behavior of households on housing price cycle. The estimation result on the interaction variables suggest that the change in housing price become more persistent in the periods after LTV implementation. It transforms into an autoregressive $\operatorname{AR}(1)$ form. The result suggests that LTV implementation leads to households becoming more backward-looking in forming their expectation. As mentioned by White (2015) who separated the factors determining housing price into cyclical and structural influences ${ }^{7}$, we argue that LTV in Indonesia brings about structural change where housing price movement become more persistent. It is imperative for policymakers to understand this finding, as now that LTV has been implemented, a shock in housing price might have prolonged impact on housing market.

\section{Conclusion}

Housing has become an important element of most economies, especially those with vast growing and developed financial sector. The previous great recession in the developed countries proved that a stable housing market is essential to maintain a sustainable financial sector and macro stability. In the micro perspective, a stable and inclusive housing sector is also indispensable to ensure societies' welfare. Noting these importance, and the detrimental effect of housing price bubble, we study the factors influencing movement in housing price with Indonesia as the focus.

${ }^{7}$ Cyclical influences only apply in the short run, while structural change leads to a consistent change of behavior in the long run. 
Jurnal Ekonomi Pembangunan, 18 (2), 2017, 225-238

The novelty of this study lies in relating LTV policy to housing price in Indonesia and further assessing its short and long run relation. As far as the authors' knowledge, studies regarding LTV in Indonesia are limited to assessing its impact on the level of mortgage credit and stock prices in the property sector, however its impact on housing price has yet been evaluated. Analyzing housing price is imperative, since the bubbling of property price has been acknowledged as a potent source of financial crisis. Furthermore, while the development of housing price affects financial sector performance, it also governs a significant proportion of household wealth and their capability to leverage assets.

Using time series data from 2003Q1 to 2017Q1, we found that per capita income, mortgage loan, stock market index, and LTV have positive long-run influence on housing price. While per capita income naturally raises the demand for housing, hence price, the property financing also has a critical role in forming demand. The finding is favored by reality that most of residential properties are purchased through mortgage loan. The mortgage loan allows households to acquire residential property without having the full amount of money in the time of purchase, however by pledging their future income as the payment. Easing the purchase for housing, it raises the demand hence price. Another financial market condition which found to be affecting the housing cycle is the stock market index. It is found that stock market index has a positive long run influence on housing price. This may due to the wealth effect generated from the stock market ${ }^{8}$. It also supports the notion that, as an investment alternative, housing market is not a substitute for financial market in Indonesia.

For the policy alternatives, we found that LTV is an effective instrument to alter housing price in the long run, while interest rate is found to be undependable in both short and long horizon. LTV has a significant positive relationship with housing price, suggesting the effectiveness of this

${ }^{8}$ See Poterba (2000) and Sutton (2002). policy in dampening housing price cycle. The effect of LTV on housing price, however, needs time to take into effect (approximately three years). In the upsurge of housing price, the central bank can impose stricter LTV to restrict the housing price growth. The lower LTV affects household decision since it constraints their ability to borrow, thus reducing the demand for housing. Contrarily, a dip in housing price that is considered to be dangerous can be dealt with the loosening of LTV (raising LTV ratio).

Further, LTV is found to change the expectation formation of household regarding the housing price movement. The housing price become more persistent in the periods after LTV implementation. This means that a shock on housing price would dies out more slowly. On one hand, it reflects that imposing LTV would make the cyclical price movement become stronger ${ }^{9}$. On the other hand, it limits the overly optimistic expectation on housing price, since expectation is anchored to the past price movement. Policymaking needs to take into account these conditions as a caveat.

Further studies may consider regional differences and spatial features in housing price formation, since Indonesia has diverging economic conditions in each of its region. Different kinds of LTV might also be discussed, such as the endogenous LTV or threshold-based LTV adjustment, in order to identify which mechanism is more efficient in delivering policy objective. A study incorporating property tax in hampering price bubble is also promising as it directly affects the incentive structure for household to hold property.

\section{Acknowledgements}

Authors are grateful to CES UNPAR for holding economics discussion forum which have given us useful comments on developing our study. We also thank the Reviewers and Editors from JEP:KMEP for their inputs and contributions in improving this paper.

${ }^{9}$ See Glindro et al. (2011) for further explanation of cyclical term in housing price movement. 


\section{References}

Allen, F., \& Gale, D. (2000). Bubbles and crises. The Economic Journal, 236-255.

Allen, F., \& Gorton, G. (1993). Churning bubbles. Review of Economic Studies, 60, 813-836.

Andrews, D. (2010). Real house prices in OECD countries: The role of demand shocks and structural and policy factors. OECD Economics Department Working Papers(831), 1-34.

Angelini, P., Neri, S., \& Panetta, F. (2012). Monetary and macroprudential policies. ECB Working Paper Series No. 1449, 1-34.

Carroll, C., Otsuka, M., \& Slacalek, J. (2011). How large are housing and financial wealth effects? A new approach. Journal of Money, Credit and Banking, 43(1), 55-79.

Catte, P., Girouard, N., Price, R. W., \& André, C. (2004). Housing market, wealth, and the business cycle. OECD Economics Department Working Papers(394), 1-41.

De Long, B., Shleifer, A., Summers, L., \& Waldmann, R. (1990). Positive feedback investment strategies and destabilizing rational speculation. Journal of Finance, 45, 379-395.

Deng, Y., Quigley, J., \& Van Order, R. (2000). Mortgage terminations, heterogeneity, and the exercise of mortgage options. Econometrica, 68, 275-307.

Eddie, C., \& HuiShen Yue. (2006). Housing price bubbles in Hong Kong, Beijing and Shanghai: A comparative study. Journal of Real Estate Finance and Economics, 33(4), 299-327.

Elu, R. (2006, Quarter 3). Residential Mortgage Default. Retrieved from www. philadelphiafed.org: https://www. philadelphiafed.org/-/media/research-anddata/publications/business-review/2006/q3/ br_q3-2006-3_residential_mortgage.pdf

Engle, R. F., \& Granger, C. W. (1987). Co- integration and error correction: Representation, estimation, and testing. Econometrica, 55(2), 251-276.

Funke, M., \& Paetz, M. (2012). A DSGE-based assessment of nonlinear loan-to-value policies: Evidence from Hong Kong. BOFIT Discussion Paper No. 11, 1-26.

Glindro, E. T., Shubanij, T., Szeto, J., \& Zhu, H. (2011). Determinants of house prices in nine Asia-Pacific economies. International Journal of Central Banking, 7(3), 163-204.

Iacoviello, M. (2005). House prices, borrowing constraints, and monetary policy in the business cycle. American Economic Review, 95(3), 739-764.

Iacoviello, M. (2010). Housing market in DSGE models: Findings and new directions. Heidelberg, Berlin: Springer.

Iacoviello, M., \& Neri, S. (2010). Housing market spillovers: Evidence from an estimated DSGE model. American Economic Journal: Macroeconomics, 2(2), 125-164.

Igan, D., \& Kang, H. (2011). Do loan-to-value and debt-to-income limits work? Evidence from Korea. International Monetary Fund Working Paper(297), 1-20.

Igan, D., \& Loungani, P. (2012). Global housing cycles. International Monetary Fund Working Paper(217), 1-50.

Kitotaki, N. (1997). Credit cycles. Journal of Political Economy, 105(2), 211-248.

Morgan, P. J., Regis, P. J., \& Salike, N. (2015). Loan-to-value policy as a macroprudential tool: The case of residential mortgage loans in Asia. Asian Development Bank Institute Working Paper(528), 1-25.

Poterba, J. (2000). Stock market wealth and consumption. Journal of Economic Perspectives, 14(2), 99-118.

Rubio, M., \& Carrasco-Gallego, J. A. (2014). Macroprudential and monetary policies: Implications for financial stability and 
Jurnal Ekonomi Pembangunan, 18 (2), 2017, 225-238

welfare. Journal of Banking and Finance, 49, 326-336.

Shwartz, H. (2012). Housing, the welfare state, and the global financial crisis: What is the connection? Politics and Society, 40(1), 3556.

Sutton, G. D. (2002, September). Explaining changes in house prices. BIS Quarterly Review, 46-55.

Taltavull de La Paz, P., \& White, M. (2012). Fundamental drivers of house price change: The role of money, mortgages, and migration in Spain and the United Kingdom. Journal of Property Research, 29(4), 341-367.

Tirole, J. (1982). On the possibility of speculation under rational expectations. Econometrica, 50, 1963 .

Tirole, J. (1985). Asset bubbles and overlapping generations. Econometrica, 53, 1499-1528.

Tsatsaronis, K., \& Zhu, H. (2004, March). What drives housing price dynamics: Cross- country evidence. BIS Quarterly Review, 65-78.

White, M. (2015). Cyclical and structural change in the UK housing market. Journal of European Real Estate Research, 8(1), 85103.

Wilson, P., White, M., Dunse, N., Cheong, C., \& Zurbruegg, R. (2011). Modelling price movements in housing micro markets: Identifying long-term components in local housing market dynamics. Urban Studies, 48(9), 1853-1874.

Wong, E., Fong, T., Li, K.-f., \& Choi, H. (2011). Loan-to-value ratio as a macro-prudential tool: Hong Kong experience and crosscountry evidence. Hong Kong Monetary Authority Working Paper(1), 1-25.

\section{(Footnotes)}

1 The null hypothesis of ADF test is that the series has a unit root (non-stationary). 